DOI: $10.17805 / z p u .2017 .2 .24$

\title{
«Мера за меру»У. Шекспира и мистерии: сюжет о воскрешении Лазаря
}

\author{
Н. В. ШипиловА
}

\section{ПРАВОСЛАВНЫЙ СВЯТО-ТИХОНОВСКИЙ ГУМАНИТАРНЫЙ УНИВЕРСИТЕТ}

В настоящей статье предпринимается попытка проанализировать традицию средневековой мистерии в «проблемной» пьесе «Мера за меру». Несмотря на использование Шекспиром итальянского источника, новеллы Джиральди Чинтио «История Эпитии» из сборника «Гекатомити», пьеса не превращается в полной мере в неоклассическую комедию в итальянском духе. Важность таких противопоставленных тем, как неправедный мирской суд и высшая справедливость Божьего суда, закон и милосердие, связывает шекспировский текст с проблематикой средневекового религиозного театра, а через нее - с евангельской традицией.

Пьесы, посвященные воскрешению Лазаря, имеются в сохранившихся текстах Йоркского, Честерского и Таунлийского циклов, а также в цикле пьес «города N». Хотя их композиционное расположение различно в разных циклах, значимость драмы о величайшем чуде Христа для жанра мистерии неоспорима.

Монолог Клаудио о смерти восходит к средневековой апокрифической традиции Visio Lazari, повлиявшей также на тексты мистерий, - рассказа воскресшего Лазаря о загробных муках. В то же время загадочное молчание закутанного в плащ Клаудио в финале пье- 
сы может быть связано уже напрямую с текстом Евангелия от Иоанна, где воскресший Лазарь предстает перед скорбящими родными с лицом, обвязанным платком, и воспринято как воплощение тайны смерти.

Поведение Изабеллы и Марианы в заключительном акте даже внешне напоминает о Марии и Марфе, преклонивших колени перед Христом. Однако на этот раз они молят пощадить Анджело, и дарованное ему помилование позволяет говорить о хотя бы потенциальной возможности его раскаяния и духовного воскрешения. Наиболее сложной для интерпретации оказывается фигура Герцога: хотя его роль в сюжете может быть сопоставлена с ролью Христа в мистерии, он становится лишь отчасти богоподобной фигурой, но не Богом, а его слишком человеческие слабости и промахи позволяют пьесе сохранять баланс между аллегоричностью и психологизмом.

Ключевые слова: У. Шекспир; «Мера за меру»; Лазарь; мистерии; средневековый театр; история литературы; английская литература

\section{ВВЕАЕНИЕ}

$\mathrm{B}$ настоящей статье предпринимается попытка проанализировать традицию средневековой мистерии в так называемой проблемной пьесе У. Шекспира «Мера за меру» на примере использования единственного, но чрезвычайно важного евангельского сюжета - истории о чуде с воскрешением $\Lambda$ азаря.

Несмотря на использование Шекспиром итальянского источника, новеллы Ажиральди Чинтио «История Эпитии» из сборника «Гекатомити» (1565), «Мера за меру» не превратилась в полной мере в неоклассическую комедию в итальянском духе. Связь пьесы с традициями средневекового театра, в частности моралите, была отмечена еще М. Брэдбрук (Bradbrook, 1941). Аллегорическая интерпретация «Меры за меру» Бэттенхауса, возводящая главную тему пьесы к христианской доктрине искупления, также опирается на средневековую традицию (Battenhouse, 1946).

Важность таких противопоставленных тем, как неправедный мирской суд и высшая справедливость Божьего суда, закон и милосердие, тесно связывает шекспировский текст с проблематикой средневекового религиозного театра, а через нее с евангельской традицией.

Аанная работа ставит своей целью проанализировать сюжетные и текстовые параллели между драмой Шекспира и средневековыми пьесами о чуде в Вифании.

\section{СЮЖЕТ О ААЗАРЕ В МИСТЕРИЯХ}

Рассмотрим вначале, как использовался сюжет о воскрешении Аазаря в английской средневековой мистерии. Посвященные ему пьесы имеются в сохранившихся текстах Йоркского, Честерского и Таунлийского циклов, а также в цикле пьес «города $\mathrm{N}$ ». Значимость драмы о величайшем чуде Христа для жанра мистерии неоспорима, но примечательно, что при этом композиционное расположение самих пьес в разных циклах совершенно различно (причем далеко не всегда совпадает с последовательностью изложения событий в первоисточнике, 11-й главе Евангелия от Иоанна), что обусловлено в каждом из случаев сверхзадачей авторов - главной темой того или иного цикла.

В Честерском цикле пьеса о Аазаре - тринадцатая по счету; она объединяет чудо воскрешения с повествованием о другом чуде Христа, исцелении слепорожденного. Подобное объединение, вероятно, наиболее точно соответствует собственно евангельскому тексту, где ассоциируются именно эти два события, так как люди, слышавшие о первом, ждут от Христа нового, более великого чуда: «А некоторые из них сказали: не мог ли сей, отверзший очи слепому, сделать, чтобы и этот не умер?» (Ин. 11:37). 
Пьеса о слепом во французской традиции обычно содержала комический элемент (поводырь слепого представлял из себя шутовскую фигуру), однако английская пьеса о чудесах серьезна целиком: сама идея чуда является главнейшей для Честера. Розмари Вулф в исследовании, посвященном английским мистериям, возводит генеральную тему Честерского цикла к учению Григория Великого о том, что Сын Божий был послан Отцом в мир, дабы уврачевать поврежденную грехом человеческую природу (Woolf, 1972: 222). Таким образом, всякий грех Адама оказывается «исправлен» Христом. Услышав голос Христа, все дьяволы устрашились, и душа $\Lambda$ азаря быстро покинула ад.

Йоркский цикл в двадцать четвертой пьесе объединяет историю прощенной Христом грешницы и Аазаря, что опять же является ярчайшей иллюстрацией общей проблематики цикла, где главное внимание уделяется природе искушения и тому примеру, который подает Христос своим противостоянием ему. Рассказ о грешнице выступает символической параллелью эпизоду Искушения Христа; одновременно как именно женский образ грешница для средневекового сознания видится своего рода антиподом образа Богородицы (как и Ева). При этом евангельская грешница не является лишь олицетворением порока и не застыла в грехе: она свободно признает его и способна на покаяние.

Соединение сюжета о прощении с историей Аазаря в Йоркском цикле создает проблематику, крайне важную для Шекспира: подобная композиция устанавливает связь между властью отпускать грехи и властью воскрешать умерших - связь, которая присутствует и в «Мере за меру» (хотя «воскрешение» у Шекспира, конечно, является символическим).

$\mathrm{B}$ цикле пьес «города $\mathrm{N}$ непосредственно чуду воскрешения $\Lambda$ азаря предшествует крайне подробно описанная сцена его смерти, содержащая множество трогательных бытовых подробностей. Почувствовав слабость, он ложится в постель, сестры, надеясь приободрить и вернуть ему силы, заботливо спрашивают, что ему приготовить поесть, и т. А. Здесь возникают аллегорические фигуры «четырех утешителей», которые сначала подбадривают Марфу и Марию, говоря, что некоторые люди исцелялись и на смертном одре, а после смерти $\Lambda$ азаря утешают скорбящих сестер тем, что на все воля Господня и умереть предстоит каждому. Сестры, находясь в отчаянии, яростно противостоят этим доводам и не желают покорно принимать смерть дорогого им человека.

Сцена с утешителями у смертного одра восходит, по-видимому, к традиции Ars moriendi - «Искусства умирать». Изначально оно представляло собой собрание средневековых текстов, которыми пользовались священники при отпевании умершего, потом появились иллюстрированные книги, с XV в. имевшие хождение уже и среди мирян (Холл, 2004: 640). Тексты были проиллюстрированы гравюрами и повествовали о том, как должно принимать смерть христианину. Особенную популярность они обретали по понятным причинам после эпидемий чумы.

\section{ШЕКСПИРОВСКАЯ ИНТЕРПРЕТАЦИЯ

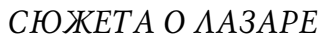

В «Мере за меру» с фигурой «утешителя» может быть сопоставлен переодетый монахом Герцог, который в тюрьме произносит для Клаудио знаменитый монолог, осуждающий жизнь, призывающий отринуть ее мимолетные ценности и не страшиться смерти, т. е. как раз и обучает Клаудио «искусству умирать»: 
.... breath thou art,

Servile to all the skyey influences,

That dost this habitation, where thou keep'st,

Hourly afflict: merely, thou art death's fool;

For him thou labour'st by thy flight to shun

And yet runn'st toward him still. Thou art not noble;

For all the accommodations that thou bear'st

Are nursed by baseness. Thou'rt by no means valiant;

For thou dost fear the soft and tender fork

Of a poor worm. Thy best of rest is sleep,

And that thou oft provokest; yet grossly fear'st

Thy death, which is no more. Thou art not thyself;

For thou exist'st on many a thousand grains

That issue out of dust

(Shakespeare, 2006: 137).

Клаудио, в отличие от Марфы и Марии в мистерии, эти слова воспринимает, казалось бы, с покорностью и благодарностью, но его спокойствие только кажущееся рассказ сестры и ее непреклонность снова быстро приводят Клаудио в отчаяние.

Сцену разговора Изабеллы с Клаудио в тюрьме интересно сопоставить уже с другим циклом мистерий, Таунлийским, в котором роль пьесы о Аазаре также крайне примечательна: она занимает предпоследнее место в цикле и, что особенно важно, следует уже после Воскресения - т. е. это уже не буквальная, хронологическая, а символическая последовательность (в Таунли и сама организация цикла принципиально иная, от Сотворения мира). Чуду о воскрешении Мазаря непосредственно предшествует пьеса о Страшном Суде. Остальные чудеса Христа в цикле не изображены: чудо воскрешения из мертвых настолько велико, что способно заменить собою все прочие.

Пьеса Таунлийского цикла использует средневековую апокрифическую традицию

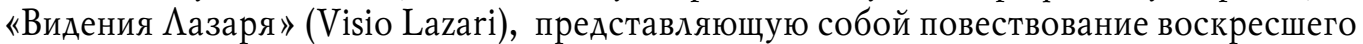
$\Lambda$ азаря о загробных муках. K этой же традиции, во всяком случае отчасти, восходит и монолог отчаявшегося Клаудио, который воображает собственную скорую гибель.

Аазарь из Таунли начинает говорить сразу после воскрешения; это очень длинный монолог, в котором часто меняется сам ритм стиха, естественным образом имитируя сбивчивую, прерывистую речь потрясенного человека:

Youre flesh that fare was here

Thus rufully shall rote;

In stede of fare colore

Sich bandys shall bynde youre throte.

Youre rud that was so red / youre lyre the lylly lyke,

Then shall be wan as led / and stynke as dog in dyke;

Wormes shall in you brede / as bees dos in the byke,

And ees out of youre hede / Thus-gate shall paddokys pyke;

To pike you ar preste

Many vncomly beest,

Thus thai shall make a feste

Of youre flesh and youre blode

(The Towneley Cycle: Электронный ресурс). 
Клаудио думает о мучениях души, отделившейся от тела и страдающей в аду, но, как и Аазарь из Таунли, страшится также и мучений души, оставшейся в гниющем теле и наблюдающей весь процесс его распада.

Беатрис Гроувз отмечает также сходство аллитераций в тексте мистерии и у Шекспира: Аазарь из Таунли говорит, как ужасно быть 'closid colde in clay', на том же звуке строится аллитерация у Клаудио ('cold...become |A kneaded clod') (Groves, 2007: 165). В обоих случаях персонажи задыхаются, словно погребенные под землей.

Наконец, интереснейшие параллели со средневековой театральной традицией можно увидеть в финале «Меры за меру». Клаудио считается казненным, и, хотя зрителям известна правда, для большинства героев пьесы его появление - действительно своего рода «воскрешение».

Когда тюремщик выводит Клаудио на сцену, в ремарке указано muffled, т. е., «повидимому», Клаудио что-то накинули на голову: плащ, как в переводе Т. ЩепкинойКуперник (Шекспир, 1994: 357), или даже мешок. Его лицо открывают лишь спустя некоторое время, что сохраняет интригу пьесы, еще на несколько мгновений оттягивая благополучную развязку.

В то же время загадочное молчание Клаудио в финале пьесы даже после того, как он получил возможность говорить, может быть связано уже напрямую с текстом Евангелия от Иоанна, где воскресший Аазарь предстает перед скорбящими родными с лицом, обвязанным платком, и воспринято как воплощение тайны смерти. «И вышел умерший, обвитый по рукам и ногам погребальными пеленами, и лице его обвязано было платком. Иисус говорит им: развяжите его, пусть идет» (Ин. 11:44).

Гроувз отмечает, что, хотя Клаудио не единственный шекспировский персонаж, чудесным образом «воскресший», его молчание само по себе уникально для пьес Шекспира. Всех остальных - Геро, Ажульетту, Гермиону, Фальстафа и других просят заговорить, чтобы доказать, что они живы, и все герои, кроме Клаудио, действительно начинают говорить (Groves, 2007: 164).

Таким образом, можно утверждать, что в образе Клаудио используются сразу две разные традиции, связанные с сюжетом о Мазаре: апокрифический монолог о посмертных муках и каноническое молчание; обе традиции использованы в разных актах и разнесены в пьесе во времени.

Аругая ситуация из заключительного акта также явственно ассоциируется со средневековыми пьесами о Аазаре: поведение Изабеллы и Марианы, умоляющих Герцога о милосердии, даже внешне напоминает о Марии и Марфе, преклонивших колени перед Христом.

Это хорошо заметно при сравнении Шекспира с Честерским циклом, где сестры говорят:

The, lord, I honour, and no moo, kneelinge upon my kneene

(The Chester Cусle: Электронный ресурс).

Аве умоляющие коленопреклоненные женщины на сцене уже вызывали у средневекового и ренессансного зрителя четкую ассоциацию с евангельским сюжетом. Аля шекспировской пьесы это также кульминационный момент. В этой связи интересно вспомнить интерпретацию этого момента Питером Бруком: он вспоминал, как просил актрису, исполнявшую роль Изабеллы, стоять на коленях до того момента, пока она чувствовала, что больше аудитории уже не выдержать; нужно было довести напряже- 
ние зрителя до предела. На две минуты действие пьесы замирало, пока, по словам Брука, «абстрактное понятие справедливости на мгновение не становилось осязаемым для всех присутствующих» (перевод мой. - Н. Ш.) (Brook, 1996: 89).

Однако, хотя Изабелла действительно в шекспировском сюжете спасает брата, что позволяет сопоставить ее с сестрами из Вифании, в финале они с Марианой просят пощадить уже Анджело, и дарованное ему помилование позволяет говорить о хотя бы потенциальной возможности его раскаяния и духовного воскрешения. Таким образом, Анджело тоже оказывается своего рода Аазарем: в последний момент избежав гибели физической, а благодаря тому, что его замыслы потерпели крах, - и духовной, он получает возможность вступить на путь духовного перерождения.

Наиболее сложной для интерпретации оказывается фигура Герцога. Учитывая то, что именно Герцог обладает силой «воскрешать» (хоть и не буквально) умерших, он оказывается сопоставлен с Христом, что особенно подчеркивается евангельской цитатой.

Знаменитые слова Марфы из Евангелия ( «Господи, если бы Ты был здесь, не умер бы брат мой», Ин. 11:21) цитируются в мистериях; так, в цикле «города N» Марфа говорит:

A, gracyous Lord, had 3e ben here,

My brother Lazare his tyme had lyved

(The N-Town Cycle: Электронный ресурс).

В Честерском цикле они приписываются Марии, но воспроизводятся также близко к евангельскому тексту:

Had Jesus my lord binne in this, this case had not befalne

(The Chester Cycle: Электронный ресурс).

В «Мере за меру» евангельская аллюзия видна в одной из знаменитейших реплик Аюцио: “...by my troth, Isabel, I loved thy brother. If the old fantastical duke of dark corners had been at home, he had lived" (Shakespeare, 2006: 175).

Однако нетрудно заметить, что в Герцоге все-таки слишком много человеческого, чтобы считать его в полной мере аллегорической фигурой. Он совершенно по-человечески милосерден и так же по-человечески обидчив (ярчайший пример - перебранки

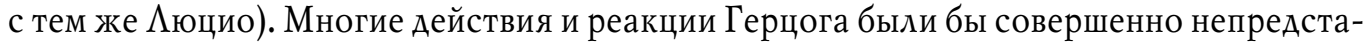
вимы для изображения Христа в средневековом театре: так, в финале он принципиально не прощает Переспелу, которая, несмотря на обилие отталкивающих черт, в общем-то, не самый страшный грешник из персонажей, к тому же сама способна на милосердие по отношению к ребенку Кэт; он долгое время мучает неведением Изабеллу. Наконец, при всем своем красноречии он не имеет совершенно никаких способов воздействия ни на Клаудио, ни тем более на несгибаемого Барнардина, так что спасение становится возможным лишь благодаря счастливой случайности.

Таким образом, хотя роль Герцога в сюжете может быть сопоставлена с ролью Христа в мистерии, он становится лишь отчасти богоподобной фигурой, но не Богом, а его слишком человеческие слабости и промахи позволяют пьесе сохранять баланс между аллегоричностью и психологизмом.

\section{ЗАКАЮЧЕНИЕ}

Как писал Кокс, связь со средневековой традицией могла также дать драматургу возможность смягчить слишком «зарубежную» пьесу (Сох, 1983: 13). Итальянский 
сюжет, восходящий к Чинтио, и элементы английского средневекового театра, восходящие в конечном итоге к Евангелию, в «Мере за меру» переплетаются теснейшим образом.

Таким образом, можно утверждать, что Шекспир использует различные элементы средневековых драм, посвященных воскрешению Аазаря, не превращая пьесу в чисто аллегорическую, но и не теряя связь как с евангельской традицией, так и с ее непосредственной интерпретацией народным театром.

\section{СПИСОК АИТЕРАТУРЫ}

Холл, Аж. (2004) Словарь сюжетов и символов в искусстве : пер с англ. М. : АСТ. 655 с.

Шекспир, В. (1994) Мера за меру // Шекспир, В. Полное собрание сочинений : пер. с англ. M. : TEPPA. T. 9.624 c. C. 181-362.

Battenhouse, R. W. (1946) Measure for Measure and Christian Doctrine of the Atonement // PMLA. Vol. 61. № 4 (Dec.). P. 1029-1059. DOI: 10.2307/459104

Bradbrook, M. (1941) Authority, Truth, and Justice in Measure for Measure // The Review of English Studies. Vol. 17. №68 (Oct.). P. 385-399.

Brook, P. (1996) The Empty Space. New York: Touchstone. 176 p.

Cox, J. D. (1983) The Medieval Background of Measure for Measure// Modern Philology. Vol. 81. № 1 (Aug.). P. 1-13. DOI: 10.1086/391264

Groves, B. (2007) Texts and Traditions. Religion in Shakespeare 1592-1604. Oxford : Clarendon Press. xii, $231 \mathrm{p}$. $221 \mathrm{p}$.

Shakespeare, W. (2006) Measure for Measure. Cambridge : Cambridge University Press. xiv,

The Chester Cycle [Электронный pecypc]// From Stage to Page. URL: http://ummutility.umm. maine.edu/necastro/drama/chester/index.html (дата обращения: 28.02.2017).

The N-Town Cycle [Электронный ресурс]// From Stage to Page. URL: http://ummutility.umm. maine.edu/necastro/drama/ntown/index.html (дата обращения: 28.02.2017).

The Towneley Cycle [Электронный ресурс] // From Stage to Page. URL: http://ummutility. umm.maine.edu/necastro/drama/towneley/index.html (дата обращения: 29.03.2017).

Woolf, R. (1972) The English Mystery Plays. Berkeley ; Los Angeles : University of California Press. vi, $440 \mathrm{p}$.

Aата поступления: 29.03.2017 2.

\section{W. SHAKESPEARE'S “MEASURE FOR MEASURE” AND MYSTERY PLAYS: \\ THE PLOT OF THE RAISING OF LAZARUS \\ N. V. SHIPILOVA \\ ST. TIKHON'S ORTHODOX UNIVERSITY}

This paper makes an attempt to examine the tradition of medieval mystery plays in the «debatable» play 'Measure for Measure'. Although Shakespeare uses an Italian source, a novel by Giraldi Cinzio «The Story of Epithy» from his collection «Ecatommiti", the play does not entirely become an Italian-style neoclassical comedy. The importance of such contrasting themes as unrighteousness of mundane court and justice of heaven, law and mercy, connects Shakespeare's text with the issues of the Medieval religious theatre and eventually with the tradition of Gospels.

The subject of the Raising of Lazarus was dramatized in the extant texts of York and Chester cycles, as well as in the Towneley and the «N Town» plays. Their place in the overall composition of different cycles may vary, but the story of Christ's greatest miracle is undoubtedly significant for the genre of all plays.

Claudio's soliloquy on death originates in the medieval apocryphal tradition of Visio Lazari, which also influenced mystery plays, including the raised Lazarus's story of the afterlife torments. At the 
same time, the re-appearance of Claudio, muffled and in enigmatic silence, can be traced back to the Gospel of John where the raised Lazarus appears before his mourning relatives with his face bound about with a scarf, and perceived as representing the mystery of death.

The behaviour of Isabella and Mariana in the final act even visually reminds the spectator of Mary and Martha kneeling before Christ. However, this time they beseech to spare Angelo's life, and the pardon granted to him may signify, at least potentially, the possibility for his soul to repent and be resurrected. The character of the Duke appears to be the most complicated to interpret: though his role in the plot can be associated with the role of Christ in mystery plays, he is only a God-like figure, not God Himself, and the human nature of all his weaknesses and failures provides the play with a perfect balance between the allegorical and the psychological modes.

Keywords: W. Shakespeare; "Measure for Measure"; Lazarus; mystery plays; medieval theatre; history of literature; English literature

\section{REFERENCES} Russ.).

Hall, J. (2004) Slovar' siuzhetov $i$ simvolov v iskusstve, transl. by Engl. Moscow, AST. 655 p. (In

Shakespeare, W. (1994) Measure for Measure. In: Shakespeare, W. Polnoe sobranie sochinenii. Moscow, TERRA. Vol. 9. 624 p. Pp. 181-362. (In Russ.).

Battenhouse, R. W. (1946) 'Measure for Measure' and Christian Doctrine of the Atonement. PMLA, vol. 61, no. 4 (Dec.), pp. 1029-1059.

Bradbrook, M. (1941) Authority, Truth, and Justice in 'Measure for Measure'. The Review of English Studies, vol. 17, no. 68 (Oct.), pp. 385-399.

Brook, P. (1996) The Empty Space. New York, Touchstone. 176 p.

Cox, J. D. (1983) The Medieval Background of 'Measure for Measure'. Modern Philology, vol. 81, no. 1 (Aug.), pp. 1-13.

Groves, B. (2007) Texts and Traditions. Religion in Shakespeare 1592-1604. Oxford, Clarendon Press. xii, $231 \mathrm{p}$. $221 \mathrm{p}$.

Shakespeare, W. (2006) Measure for Measure. Cambridge, Cambridge University Press. XIV,

The Chester Cycle. From Stage to Page. From Stage to Page [online] Available at: http://ummutility.umm.maine.edu/necastro/drama/chester/index.html (access date 28.02.2017).

The N-Town Cycle. From Stage to Page. From Stage to Page [online] Available at: http://ummutility.umm.maine.edu/necastro/drama/ntown/index.html (access date 28.02.2017).

The Towneley Cycle. From Stage to Page. From Stage to Page [online] Available at: http://ummutility.umm.maine.edu/necastro/drama/towneley/index.html (access date 28.02.2017).

Woolf, R. (1972) The English Mystery Plays. Berkeley and Los Angeles, University of California Press. vi, $440 \mathrm{p}$.

Submission date: 29.03.2017.

Шипилова Наталия Витальевна - кандидат филологических наук, старший преподаватель кафедры германской филологии филологического факультета Православного Свято-Тихоновского гуманитарного университета. Адрес: 125480, Россия, г. Москва, ул. Героев Панфиловцев, А. 1. Тел.:+7 (495) 494-01-64. Эл. адpec: mezora@mail.ru

Shipilova Natalia Vitalievna, Candidate of Philology, Senior Lecturer, Department of Germanic Philology, Faculty of Philology, St. Tikhon's Orthodox University. Postal address: 1, Geroyev Panfilovtsev St., Moscow, Russian Federation 125480. Tel.: +7 (495) 494-01-64. E-mail: mezora@mail.ru 